\title{
Nancy K. Bristow. Steeped in the Blood of Racism: Black Power, Law and Order, and the 1970 Shootings at Jackson State College
}

\author{
New York: Oxford University Press, 2020. 320 pp.
}

\author{
Susan Eckelmann Berghel (D) \\ University of Tennessee Chattanooga \\ Susan-Eckelmann@utc.edu
}

A deep dive into the archive and new testimonies, Nancy Bristow's Steeped in the Blood of Racism exposes how White supremacy, state-sanctioned violence, and national amnesia intersect and have undermined the rights and safety of Black Americans. Bristow's careful assessment of the 1970 Jackson State College shootings and its aftermath equips readers with the tools to contextualize and unpack presentday media narratives of the ongoing racial terrorism. Bristow's book presents a gutwrenching truth. While Americans have forgotten the assault at Jackson State, its past is the present: the uneven coverage and criminalization of Black youth activism, the fabricated victimization of White Americans, and the killings of innocent Black citizens at the hands of law enforcement officers. Police violence continues to pose danger-not just to communities of color who are disproportionally targeted, but to American democracy. Published fifty years after the tragedy occurred, Steeped in the Blood of Racism demands accountability, or else, Americans will continue to choke on this fishbone of denial.

Since the founding of Jackson State College, then known as Natchez Seminary, in 1877, the school's leadership has consistently "walked a tightrope" between achieving Black advancement and adhering to the dictates of White supremacy (p. 21). As Bristow demonstrates in chapter 1, the state's "closed society" kept Black aspirations in check relying on segregation, discrimination, and violence to maintain White power. When Jackson State became swept up by the change in tide during the 1960s, the school's president, Jacob Reddix, suppressed student activism. He frequently expelled dissidents and abolished the Student Government Association. His unwillingness to challenge the Board of Trustees' racism and the city of Jackson's outright criminalization of Black students earned him the title of "worst kind of sellout" among the students (p. 36). As long as Jackson State's administration and its student body conformed to White demands and preserved White residents' racial comfort, the city's power balance was preserved. Bristow's sharp analysis exposes the racialized campus geography before and after the shootings-the battle over space and security. Black students' bodies became targets of ongoing traffic that cut through the campus, as occurred when a car hit and seriously injured student Mamie Ballard.

(C) History of Education Society 2021 
Bristow highlights the administrative power exerted and risks taken by Reddix's successor and Jackson State alumnus, John Peoples. In contrast to his predecessors, Peoples listened to the students and showed compassion for their concerns. Under his leadership, the university built the Institute for the Study of History, Life and Culture of Black People. The shootings at Jackson State reveal that his administration's empowerment of students threatened White residents' sense of racial hierarchy in the city. As historian Carol Anderson maintains, White people respond to Black advancement with rage. When President Peoples diverted from the path of compliance by restoring the Student Government Association and encouraging students' voices, law enforcement increasingly turned to violence. Law-and-order rhetoric was already entrenched in local discourses, as Bristow powerfully shows through her examination of newspaper coverage and political speeches. Chapter 2 reveals that President Richard Nixon's law-and-order campaign slogan was a product of an existing lexicon and practice before he helped nationalize and institutionalize it through public policies.

In Chapter 3, Bristow traces the tensions between students and local law enforcement on campus leading up to May 15 and sets the historical record straight. When a glass bottle struck the pavement, Bristow writes, law enforcement fired over 150 rounds-nearly 400 bullets or buckshot. Bristow underscores that the shootings embodied White terrorism. This "hyper-militarized approach" and "the reckless disregard" for protocol exposed White rage and the dispensability of Black bodies. A Black police officer, a physician, and a faculty member echoed students' chilling conclusion that the shootings were a "planned massacre" (p. 83). Chapter 3 exposes the degree to which officers lacked training and ignored existing protocols, and shows how their claims about the existence of a sniper could not be substantiated. While students experienced death, injuries, and trauma, law enforcement's priorities focused on the removal of critical evidence and hampered the investigation. Two students died and twelve students were injured while police and state troopers remained unharmed. Bristow's chilling reconstruction of the events remind the reader that "the suffering and loss" in the wake of the racialized murder "is impossible to fathom" (p. 98). Bristow humanizes the victims of the tragedy.

Chapter 4 meticulously chronicles three competing narratives that emerged in the wake of the shootings and offers a powerful explanation of what caused people to disremember the 1970 onslaught. The first narrative centered on the shootings as the product of a "brutal white supremacist assault," while a second narrative framed the police's militarized overreaction as an attack on the students' bid to erase racism. Despite the carefully conducted mayoral and presidential investigations that proved law enforcement's racism in producing the tragedy, these narratives became overshadowed by a counter-narrative that reversed the roles of victims and aggressors. This narrative recast the "police as a bulwark against the forces of anarchy and lawlessness" (p. 124). Bristow details how, shortly after the shootings, student activists anticipated law enforcement's plans to erase historical memory and organized to block the highway patrol's attempt to remove the damaged walls and dormitory windows. Prominent national figures and commentators across the nation shared students' outrage. Yet, the city's decision to erect a barricade on Lynch Street in the wake of the shootings cemented the power of the law-and-order narrative. 
Two grand juries refused to convict law enforcement officers for their crimes. Chapter 5 recounts the legal proceedings during the civil suit Myrtle Green Burton et al. v. John Bell Williams et al. in 1972-the only remaining path for the survivors and the families of the murdered students to sue for damages. This chapter documents the lasting physical impairments of the survivors, lifelong emotional pain and trauma, the impact on families, and, even if temporarily, the delay of some students' educational pursuits. Bristow also uncovers how the gendered and racialized dynamics among the plaintiffs' legal team almost jeopardized the civil suit. The plaintiffs' counsel focused on law enforcement officers' insufficient training and obvious racial motivations during and after the shootings. The defense discredited and denigrated the witnesses, stressing their racial identity and exposing humiliating medical information. By framing the shootings as an act of self-defense, the defense credited law enforcement with the preservation of peace. In the end, defendants evaded legal consequences by invoking sovereign immunity. The civil suit further solidified the law-and-order rhetoric and denied the victims justice.

The final chapter exposes the efforts and failures to commemorate the Jackson State shootings as the product of state-sanctioned racial terror. Bristow shows that the burden of remembering the events rested on the shoulders of the victims and their families. Jackson State students hosted cultural events and workshops. Eventually, Jackson State funded the construction of Gibbs-Green Memorial Plaza, named after the two men killed. Mississippi's recent commemorative efforts, as Bristow astutely points out, are driven by an "entrepreneurial impulse" to "benefit financially from growing interest in the history of the struggle for civil rights" (p. 185). Public acknowledgment of Black victimhood and trauma is possible when it is monetized. Bristow presents a convincing explanation for the collective forgetting of the Jackson State shootings. This is when the book hits its stride. She writes, "The triumphal narrative of American democracy" leaves little room "for the assault at Jackson State and the failure of the justice system in the aftermath" (p. 174). Today, Jackson State struggles to attract students' interest in annual commemorations. As one local observer maintains, "there's no connection, there's no interest" (p. 186).

Steeped in the Blood of Racism visually catalogues the militarized overreaction that cost innocent lives. Photographs of the bullet-riddled building facades and destroyed windows bear witness to the violence that has been overshadowed by the Kent State shootings and the law-and-order narrative that framed the Jackson State tragedy and its aftermath. Bristow recasts powerful evidence and features images of the victims of state-sanctioned racialized murder, calling on American educators to correct conventional textbook narratives that have erased this important history and to challenge contemporary students' celebratory notion that the civil rights era ushered in a postracial society. By demonstrating how the past led to the present and how the present mirrors the past, Bristow invites readers to see more clearly and fight against the racism that fuels police terrorism today. 